\title{
ERRATA
}

\section{Description of Bacillus laevolacticus (ex Nakayama and Yanoshi 1967) sp. nov., nom. rev.}

I. ANDERSCH, S. PIANKA, D. FRITZE, AND D. CLAUS

DSM-Deutsche Sammlung von Mikroorganismen und Zellkulturen GmbH, D-38124 Braunschweig, Germany

Volume 44, no. 4, p. 662, Table 3, column 5, lines 8 and 9: the data for $B$. smithii growth in NB at pH 4.5 and pH 6.8 of “+” and "-" should read "-_" and " + ," respectively.

\section{Transfer of "Pseudomonas riboflavina" (Foster 1944), a Gram-Negative, Motile Rod with Long-Chain 3-Hydroxy Fatty Acids, to Devosia riboflavina gen. nov., sp. nov., nom. rev. \\ YASUYOSHI NAKAGAWA, TAKESHI SAKANE, AND AKIRA YOKOTA \\ Institute for Fermentation, Osaka, Yodogawa-ku, Osaka 532, Japan}

Volume 46, no. 1, p. 17, Table 1, last line: "Oxidation of riboflavin ... - " should read "Oxidation of riboflavin ... +." Page 21, column 1, line 29: "No 2-OH hydroxy acid is present" should read "No 2-OH fatty acid is present."

\section{Culture and Characteristics of Helicobacter bizzozeronii, a New Canine Gastric Helicobacter sp. \\ MARJA-LIISA HÄNNINEN, I. HAPPONEN, S. SAARI, AND K. JALAVA}

Department of Food and Environmental Hygiene, Department of Veterinary Clinical Sciences, and Institute of Pathology, Faculty of Veterinary Medicine, University of Helsinki, 00581 Helsinki, Finland

Volume 46 , no. 1 , p. 165 , column 2, line 25: the last line of the text should read as follows: "The type strain is CCUG 35045 (Culture Collection of the University of Göteborg, Göteborg, Sweden)." 